\title{
Cotylogaster basiri Siddiqi \& Cable, 1960 (Aspidobothrea: Aspidogastridae) in Pogonias cromis (Linnaeus, 1766) (Perciformes: Sciaenidae): first report from Brazil
}

\author{
M. Gallas ${ }^{a *}$, E. F. Silveira ${ }^{a}$ and E. Périco ${ }^{b}$

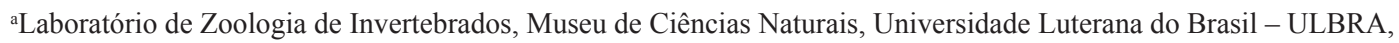 \\ Avenida Farroupilha, 8001, CEP 92425-900, Canoas, RS, Brazil \\ 'Laboratório de Ecologia, Museu de Ciências Naturais, Centro Universitário UNIVATES, Rua Avelino Tallini, 171, \\ CEP 95900-000, Lajeado, RS, Brazil \\ *e-mail:mgallas88@gmail.com
}

Received: June 29, 2015 - Accepted: November 12, 2015 - Distributed: February 28, 2017

(With 2 figures)

\begin{abstract}
Up until now, there have been few studies of the helminth fauna of Brazilian populations of Pogonias cromis. In North America, $P$. cromis is known to be a definitive host of Cotylogaster basiri, although there have been no reports of any species of Cotylogaster infecting fish in Brazil. During necropsies of marine fish obtained from professional fisherman in the state of Rio Grande do Sul, Brazil, specimens of $C$. basiri were found in the intestine and rectum of $P$. cromis. In comparison with previous studies, differences were found in relation to the number of lobes in the buccal disc and the development of the biocellate larvae in the eggs of $C$. basiri. This is the first report of $C$. basiri in $P$. cromis from Brazil, contributing to the understanding of the helminth fauna of this fish from the coastal zone of Brazil.
\end{abstract}

Keywords: Cotylaspidinae, aspidobothrean, black drum, taxonomy, Neotropical Region.

\section{Cotylogaster basiri Siddiqi \& Cable, 1960 (Aspidobothrea: Aspidogastridae) em Pogonias cromis (Linnaeus, 1766) (Perciformes: Sciaenidae): primeiro registro para o Brasil}

\section{Resumo}

Até a presente data, existem poucos estudos sobre a helmintofauna de Pogonias cromis para o Brasil. Na América do Norte, P. cromis foi registrada como hospedeira de Cotylogaster basiri e, até o presente momento, não existem registros de qualquer espécie de Cotylogaster em peixes no Brasil. Em necropsias de peixes marinhos adquiridos por pescadores profissionais, foram encontrados espécimes de $C$. basiri no intestino e reto de $P$. cromis no Estado do Rio Grande do Sul, Brasil. Quando comparada com a literatura, foram encontradas diferenças em relação ao número de lobos do funil oral e ao desenvolvimento da larva biocelar dentro dos ovos de C. basiri. Este é o primeiro registro de C. basiri em P. cromis para o Brasil, contribuindo para o conhecimento da helmintofauna desse peixe na costa brasileira.

Palavras-chave: Cotylaspidinae, aspidobótreo, burriquete, taxonomia, Região Neotropical.

\section{Introduction}

The family Aspidogastridae Poche, 1907 includes three subfamilies, containing Cotylaspidinae Chauhan, 1954 which comprises three genera with species possessing a ventral holdfast with three longitudinal rows (two marginal and one central) of alveoli (Rohde, 2002). One of these genera, Cotylogaster Monticelli, 1892, is characterized by the presence of two testes, and infects freshwater and marine fish (Rohde, 2002). Cotylogaster occidentalis Nickerson, 1902 and Cotylogaster barrowi (Huehner and Etges, 1972) have been reported in freshwater fish, and Cotylogaster michaelis Monticelli, 1892, Cotylogaster basiri Siddiqi
\& Cable, 1960 and Cotylogaster dinosoides Hendrix \& Overstreet, 1977 in marine fish species (Fredericksen, 1972; Huehner and Etges, 1972; Hendrix and Overstreet, 1977). Cotylogaster basiri was described from specimens found in Calamus calamus (Valenciennes, 1830) captured at Cabo Rojo, Puerto Rico (Siddiqi and Cable, 1960), and subsequently in hosts collected at a number of different localities in North America (Nahhas and Cable, 1964; Hendrix and Overstreet, 1977, 1983; Simpson and McGraw Junior, 1979). This parasite has been recorded in South Africa (Bray, 1984) and Venezuela (Chinchilla et al., 2000), 
but prior to the present study, there were no reports of any Cotylogaster from Brazil (Kohn et al., 2007; Alves et al., 2015).

The black drum, Pogonias cromis (Linnaeus, 1766), is found in the western Atlantic Ocean between southern Florida and Argentina (Menezes et al., 2003). This fish is found in coastal waters influenced by large rivers, or sand and mud banks, where it feeds on bottom organisms, such as crustaceans, mollusks and other fish (Menezes and Figueiredo, 1980). Prior to the present study, two species of aspidobothreans $-C$. basiri and $C$. dinosoides - had only been reported in $P$. cromis from the Gulf of Mexico (Hendrix and Overstreet, 1977; Simpson and McGraw Junior, 1979).

\section{Material and Methods}

Specimens of $P$. cromis $(\mathrm{n}=6)$ were obtained between July and August 2014 from professional fisherman in the municipality of Rio Grande ( $32^{\circ} 11^{\prime} 06$ ” S, $052^{\circ} 06$ ' 32 ” W), State of Rio Grande do Sul, Brazil. The aspidobothreans found infecting these specimens were compressed and fixed in A.F.A., stained with Delafield's hematoxylin, and mounted in Canada balsam (Amato and Pereira Junior, 1995; Humason, 1979).

The measurements are presented in micrometers $(\mu \mathrm{m})$, unless otherwise indicated. The values are presented as the range followed by the mean, standard deviation $( \pm)$, with the number of specimens measured in parentheses. Ecological terminology was based on Bush et al. (1997). The drawings were produced using a drawing tube attached to a microscope, then scanned and prepared using CorelDraw $\mathrm{X} 4{ }^{\circledR}$ and Adobes Photoshop ${ }^{\circledR}$ CS2. Voucher specimens of the helminths were deposited in the 'Coleção Helmintológica do Museu de Ciências Naturais da ULBRA' (CHMU), in Canoas, Rio Grande do Sul, Brazil.

\section{Results}

Cotylogaster basiri Siddiqi \& Cable, 1960 (Figures 1 and 2).

Description based on nine adult specimens mounted in toto. Aspidobothrea, Aspidogastridae. Body 2.12-3.38 mm (2.78 $\pm 0.44 \mathrm{~mm} ; \mathrm{n}=9)$ long, $0.8-1.49 \mathrm{~mm}(1.14 \pm 0.22 \mathrm{~mm} ; \mathrm{n}=9)$ wide at the level of the ventral holdfast. Ventral holdfast organ $1.38-2.25 \mathrm{~mm}$ $(1.86 \pm 0.3 \mathrm{~mm} ; \mathrm{n}=9)$ long, corresponding to $67 \%$ of total body length, and possessing two continuous marginal rows of $54-67(59 ; n=9)$ cuplike alveoli and a medial row of 18-23 $(20 ; n=9)$ elongate transverse alveoli. Marginal organs and papillae are found on the alveolar ridges surrounding the lateral alveoli. Tail retractile, visible in one specimen, 221 long. Buccal disc 345-690 (534 $\pm 114 ; \mathrm{n}=9)$ wide, possessing one dorsal (pointed), and two ventrolateral lobes. Neck 345-943 (588 $\pm 186 ; n=9)$ long. Eyespots dispersed in the region of the prepharynx. Prepharynx 92-267 (171 $\pm 55 ; \mathrm{n}=8)$ long; pharynx 184-253 (231 \pm 22 ; $\mathrm{n}=9)$ long, $138-253(192 \pm 34 ; \mathrm{n}=9)$ wide. Esophagus indistinct; cecum single, $1.15-1.7 \mathrm{~mm}(1.42 \pm 0.18 \mathrm{~mm}$; $\mathrm{n}=9$ ) long. Genital pore medial, anterior or posterior to the forward margin of the holdfast organ. Two testes, in tandem or diagonal, 207-299 (256 $\pm 37 ; \mathrm{n}=9)$ long, 184-276 (222 $\pm 34 ; \mathrm{n}=9)$ wide. Seminal vesicle coiled near the prostatic vesicle; prostatic vesicle elongated and surrounded by prostatic cells. Cirrus and cirrus-sac absent. Ejaculatory duct not observed. Genital atrium rounded in shape, surrounded by glandular cells. Ovary anterior or very close to the anterior testis, 138-276 (207 \pm 47 ; $\mathrm{n}=9)$ long, 92-161 (132 $\pm 22 ; \mathrm{n}=9)$ wide. Laure's canal not observed. Uterus with numerous eggs in most of the specimens, extending as far as the region of the prostatic vesicle and tail. Vitellaria U-shaped, ranging from the $9^{\text {th }}$ to $19^{\text {th }}$ lateral alveoli, $0.7-1.6 \mathrm{~mm}(1.12 \pm 0.3 \mathrm{~mm} ; \mathrm{n}=9)$ long. Eggs 45-68 (60 $\pm 8 ; n=9)$ long, 24-35 (28 $\pm 3 ; n=9)$ wide, most containing biocellate larvae.

Taxonomic summary:

Synonym: Texanocotyle pogoniae Simpson \& McGraw Jr., 1979.

Host: Pogonias cromis (Linnaeus, 1766).

Locality: Rio Grande, State of Rio Grande do Sul, Brazil - first report from Brazil.

Site of infection: posterior intestine and rectum.

Prevalence: $83.33 \%$.

Mean intensity of infection: 29.6 helminths/host.

Mean abundance of infection: 24.6 helminths/host.

Voucher specimen of helminth deposited: CHMU 203-1-1.

\section{Discussion}

Yamaguti (1963) proposed the genus Cotylogasteroides Yamaguti, 1963 for C. occidentalis which is characterized by the absence of a cirrus pouch, tubular and asymmetric vitellaria, and the presence of Laurel's canal, in addition to being found only in freshwater fish. Yamaguti (1963) considered that $C$. michaelis and $C$. basiri should remain in the genus Cotylogaster, which is diagnosed by the presence of a cirrus pouch, follicular and symmetric vitellaria, the absence of Laurel's canal, and occurs only in marine fish. However, Fredericksen (1972) considered Cotylogasteroides to be a synonym of Cotylogaster, an arrangement accepted by subsequent authors (Hendrix and Overstreet, 1977; Rohde, 2002). Zamparo and Brooks (2003) presented a phylogeny of the Aspidobothrea Burmeister, 1856, in which they revalidated Yamaguti's (1963) proposal, including the separation of Cotylogaster (C. michaelis and C. basiri) and Cotylogasteroides (Co. occidentalis and Co. barrowi). The present study nevertheless follows the generic classification of Rohde (2002) which considers Cotylogasteroides of synonym of Cotylogaster.

The $C$. basiri specimens collected in the present study presented morphometry similar to those reported by Siddiqi and Cable (1960), Simpson and McGraw Junior 

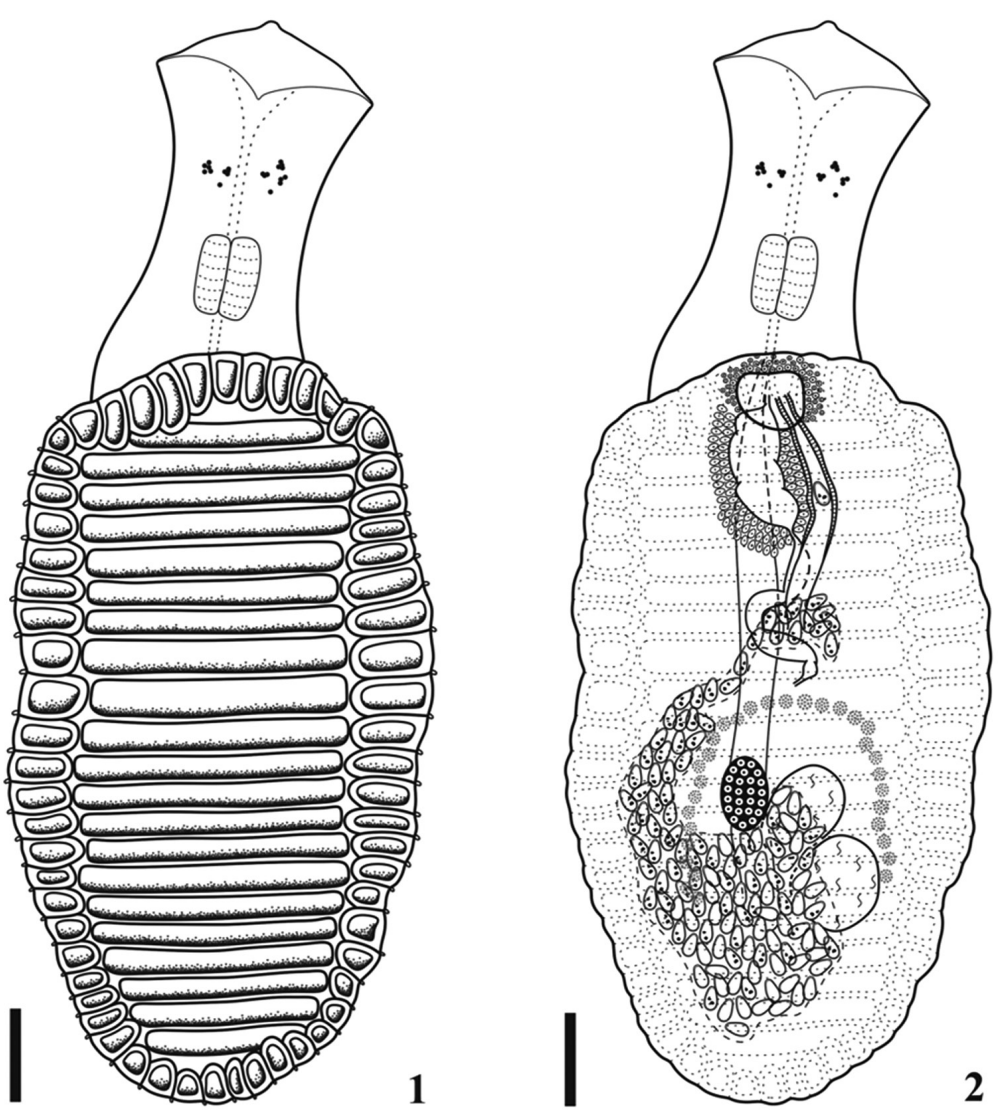

Figures 1 and 2. Incomplete diagrams of Cotylogaster basiri Siddiqi \& Cable, 1960. (1): External view of an entire specimen, showing the ventral holdfast organ with the marginal cuplike alveoli and the medial row of elongate transverse alveoli. (2): Specimen showing the internal organs. Scale bars $=250 \mu \mathrm{m}$.

(1979) and Chinchilla et al. (2000), but smaller than the specimens measured by Hendrix and Overstreet (1977). This difference may be related to the relatively long specimens $(1.55-7.34 \mathrm{~mm})$ collected by Hendrix and Overstreet (1977) in comparison with all other studies: 2.43-4.97 mm (Siddiqi and Cable, 1960), 0.99-3.97 mm (Simpson and McGraw Junior, 1979), 4.26 mm (Chinchilla et al., 2000) and 2.12-3.38 $\mathrm{mm}$ (present study).

Siddiqi and Cable (1960), Hendrix and Overstreet (1977) and Chinchilla et al. (2000) observed five lobes (two ventral, two lateroventral and one dorsal) in the buccal disc of $C$. basiri, whereas the specimens examined by Simpson and McGraw Junior (1979) had three lobes, with the dorsal one larger than the ventral ones. Siddiqi and Cable (1960) examined only three specimens of C. basiri, which may mean there was an error due the difficulty of visualizing the lobes. In the present study, three lobes were observed in the buccal disc, as described by Simpson and McGraw Junior (1979).

Bray (1984) reported a distinctly trilobated ovary in C. basiri, although the ovaries observed in the present study were smooth in form, as observed in all other studies (Siddiqi and Cable, 1960; Hendrix and Overstreet, 1977;
Simpson and McGraw Junior, 1979; Chinchilla et al., 2000). Siddiqi and Cable (1960) described a cirrus pouch in their specimens of $C$. basiri, although this organ was considered absent by Fredericksen (1972), Hendrix and Overstreet (1977), and in the present study. The cirrus pouch described by Siddiqi and Cable (1960) possibly represents the seminal vesicle or the prostatic vesicle as identified in the redescription of $C$. basiri by Hendrix and Overstreet (1977).

Siddiqi and Cable (1960), Hendrix and Overstreet (1977), Bray (1984) and Chinchilla et al. (2000) observed numerous eggs in the uterus of C. basiri, as found in the specimens examined in the present study. Here, however, only the eggs near the metraterm contained biocellate larvae, in contrast with the illustrations presented in the previous studies (Siddiqi and Cable, 1960; Hendrix and Overstreet, 1977; Bray, 1984), which depicted most of the eggs containing biocellate larvae. This different may be related to factors such as the age of the adults and the development of the eggs in the specimens observed in the present study.

A recent study recorded the occurrence of 61 species of aspidobothreans in invertebrate and vertebrate hosts 
around the world (Alves et al., 2015). In $70.5 \%$ of these cases, the parasite infects freshwater hosts, and the other $29.5 \%$, marine hosts. More than half $(60 \%)$ of the host-parasite associations recorded in marine species were observed in the northern Atlantic Ocean. This is the first report of $C$. basiri in $P$. cromis from the coastal zone of South America, contributing to the understanding of the biodiversity of aspidobothreans in marine hosts in the Neotropical Region.

\section{Acknowledgements}

We are grateful to Professor Klaus Rohde for his personal communication on the taxonomic status of Cotylogaster; Professor Robin M. Overstreet at the University of Southern Mississippi, for his help with bibliography on C. basiri, Dr. Anna J. Phillips, Smithsonian National Museum of Natural History for the photomicrographs of C. basiri and Dr. Stephen F. Ferrari (USF) for revising the English text.

\section{References}

ALVES, P.V., VIEIRA, F.M., SANTOS, C.P., SCHOLZ, T. and LUQUE, J.L., 2015. A checklist of the aspidogastrea (platyhelminthes: trematoda) of the world. Zootaxa, vol. 3918, no. 1, pp. 339-396. http://dx.doi.org/10.11646/zootaxa.3918.3.2. PMid:25781098.

AMATO, J.F.R. and PEREIRA JUNIOR, J., 1995. A new species of Rugogaster (Aspidobothrea: Rugogastridae) parasite of the elephant fish, Callorhinchus callorhynchi (Callorhinchidae), from the estuary of the La Plata River, coasts of Uruguay and Argentina. Revista Brasileira de Parasitologia Veterinária, vol. 4, no. 1, pp. 1-7.

BRAY, R.A., 1984. Some helminth parasites of marine fishes and cephalopods of South Africa: Aspidogastrea and the digenean families Bucephalidae, Haplosplanchnidae, Mesometridae and Fellodistomidae. Journal of Natural History, vol. 18, no. 2, pp. 271-292. http://dx.doi.org/10.1080/00222938400770211.

BUSH, A.O., LAFFERTY, K.D., LOTZ, J.M. and SHOSTAK, A.W., 1997. Parasitology meets ecology on its own terms: Margolis et al. revisited. The Journal of Parasitology, vol. 83, no. 4, pp. 575-583. http://dx.doi.org/10.2307/3284227. PMid:9267395.

CHINCHILLA, O.L., MAGO, G.Y.M. and ÁLVAREZ, B.M.E., 2000. Primer hallazgo de un aspidogastreo en Venezuela. Cotylogaster basiri Siddiqi y Cable, 1960 (Trematoda, Aspidogastrea), parasite de Archosargus unimaculatus (Pisces, Sparidae). Saber, vol. 12, no. 2, pp. 8-12.

FREDERICKSEN, D.W., 1972. Morphology and taxonomy of Cotylogaster occidentalis (Trematoda: Aspidogastridae). The
Journal of Parasitology, vol. 58, no. 6, pp. 1110-1116. http:// dx.doi.org/10.2307/3278150.

HENDRIX, S.S. and OVERSTREET, R.M., 1977. Marine aspidogastrids (Trematoda) from fishes in the northern gulf of Mexico. The Journal of Parasitology, vol. 63, no. 5, pp. 810-817. http://dx.doi.org/10.2307/3279883. PMid:915610.

HENDRIX, S.S. and OVERSTREET, R.M., 1983. Evaluation of the Status of Texanocotyle pogoniae and Laterocotyle padreinsulae (Trematoda: Aspidogastridae). The Journal of Parasitology, vol. 69, no. 2, pp. 431-432. http://dx.doi.org/10.2307/3281256.

HUEHNER, M.K. and ETGES, F.J., 1972. A new aspidogastrid trematode, Cotylogasteroides barrowi sp. n., from freshwater mussels of Ohio. The Journal of Parasitology, vol. 58, no. 3, pp. 468-470. http://dx.doi.org/10.2307/3278190.

HUMASON, G.L., 1979. Animal tissue techniques. 4th ed. São Francisco: W.H. Freeman and Company. 661 p.

KOHN, A., FERNANDES, B.M.M. and COHEN, S.C., 2007. South American Trematodes Parasites of Fishes. Rio de Janeiro: Imprinta Express. 318 p.

MENEZES, N.A. and FIGUEIREDO, J.L., 1980. Manual de peixes marinhos do sudeste do Brasil. IV. Teleostei (3). São Paulo: Museu de Zoologia da Universidade de São Paulo. 96 p.

MENEZES, N.A., BUCKUP, P.A., FIGUEIREDO, J.L. and MOURA, R.L., 2003. Catálogo das espécies de peixes marinhos do Brasil. São Paulo: Museu de Zoologia da Universidade de São Paulo. 160 p.

NAHHAS, F.M. and CABLE, R.M., 1964. Digenetic and aspidogastrid trematodes from marine fishes of Curacao and Jamaica. Tulane Studies in Zoology, vol. 11, no. 4, pp. 169-228. http://dx.doi.org/10.5962/bhl.part.7052.

ROHDE, K., 2002. Subclass Aspidogastrea Faust \& Tang, 1936. In: D.I. GIBSON, A. JONES and R.A. BRAY, eds. Keys to the Trematoda. Wallingford: CABI Publishing, vol. 1, pp. 5-14.

SIDDIQI, A.H. and CABLE, R.M., 1960. Digenetic trematodes of marine fishes of Puerto Rico. Scientific Survey of Porto Rico and the Virgin Islands, vol. 17, no. 3, pp. 257-369.

SIMPSON, D.T. and MCGRAW JUNIOR, J.L., 1979. Two new genera of Aspidogasteridae from Pogonias cromis (L.) from the Texas Gulf Coast. The Southwestern Naturalist, vol. 24, no. 4, pp. 557-562. http://dx.doi.org/10.2307/3670515.

YAMAGUTI, S., 1963. Systema Helminthum: Monogenea and Aspidocotylea. New York: Interscience Publishers. vol. 4. 699 p.

ZAMPARO, D. and BROOKS, D.R., 2003. Phylogenetic systematic assessment of the Aspidobothrea (Platyhelminthes, Neodermata, Trematoda). Zoologica Scripta, vol. 32, no. 1, pp. 83-93. http:// dx.doi.org/10.1046/j.1463-6409.2003.00088.x. 